\title{
Action of different genera of rumen protozoa on the in vitro degradation of three dietary proteins with different solubilities
}

\author{
JP Jouany, Y Papon, B Lassalas \\ INRA - CRZV de Theix, station de recherches sur la Nutrition des herbivores, \\ 63122 Saint-Genès-Champanelle, France
}

The presence of a mixed population of ciliate protozoa in the rumen decreases the supply of dietary and microbial proteins in the small intestine of ruminants (Jouany, 1991). In the present study, we studied the degradative activity of different rumen inocula containing only 1 or 2 genera of rumen ciliates against $3 \mathrm{~N}$ sources (fishmeal: FM, soybean meal: $\mathrm{SM}$ and casein: $\mathrm{CA}$ ) which respectively have a low, medium and high solubility.

Rumen-simulating fermentors (Jouany and Thivend, 1986) were inoculated with rumen contents sampled from defaunated sheep, or from sheep monoinoculated with Isotricha or Eudiplodinium, or inoculated with a combination of Epidinium and Entodinium, or which had a conventional type A (Polyplastron is the major cellulolytic genus) or type B (containing Epidinium and Eudiplodinium) mixted fauna. Animals were fed a mixed diet of dehydrated lucerne $(900 \mathrm{~g})$, maize grains $(300 \mathrm{~g})$ and chopped wheat straw $(100 \mathrm{~g})$. The protein fermentabilities were calculated by comparing for the same inoculum, the production of $\mathrm{NH}_{3}$ in fermentors that had been fed with the protein sources and in those that had not. We ensured that protozoa were active during the $6 \mathrm{~h}$ periods of fermentation.
Compared with results in defaunated animals, a mixed fauna increased the fermentability of FM and chiefly that of SM, but not that of the highly degradable protein (CA) (table I). Isotricha alone significantly decreased the fermentability of the 3 substrates tested. Eudiplodinium increased the degradation of the lowest soluble nitrogen source (FM); it had no effect on SM and decreased that of the highest soluble nitrogen source (CA). Epidinium and Entodinium in mixture hat no effect on FM, but they decreased the protein fermentability of SM and CA.

In conclusion, the effect of rumen ciliates on protein degradation in the rumen, and hence on the dietary protein supply in the duodenum, varies depending on whether they are present in a complex combination or in a simplified form. Some genera may even have opposite effects.

Jouany JP (1991) Rumen Microbial Metabolism and Ruminant Digestion (Jouany JP, ed) INRA Editions, 239-261

Jouany JP, Thivend P (1986) Anim Feed Sci Technol 15, 215-229

Table I. Influence of the rumen fauna on the degradation of different nitrogen sources (\% of nitrogen degraded into $\mathrm{NH}_{3}$ during 6 h of fermentation; $n=8$ ).

\begin{tabular}{|c|c|c|c|c|c|c|c|}
\hline & Defaunated & Isotricha & Eudiplodinium & $\begin{aligned} & \text { Epidinium } \\
+ & \text { Entodinium }\end{aligned}$ & \multicolumn{2}{|c|}{ Total fauna } & $S D M$ \\
\hline Fish meal & $22.7^{a}$ & $17.2^{\circ}$ & $26.1^{c}$ & $20.2^{a}$ & ND & $26.5^{c}$ & 20 \\
\hline Soyabean meal & $41.8^{a}$ & $28.1^{b}$ & $44.0^{\mathrm{a}}$ & $37.2^{\mathrm{c}}$ & ND & $51.1^{\mathrm{d}}$ & 1.8 \\
\hline Casein & $83.2^{\mathrm{a}}$ & $70.5^{b c}$ & $74.1^{\mathrm{b}}$ & $67.0^{c}$ & $83.2^{\mathrm{a}}$ & $82.0^{\mathrm{a}}$ & 2.6 \\
\hline
\end{tabular}

